\title{
A STUDY OF PYRAMIDAL CELL AXON COLLATERALS IN INTACT AND PARTIALLY ISOLATED ADULT CEREBRAL CORTEX
}

\section{T. RUTLEDGE, JOYCE DUNCAN AND NELL BEATTY}

Department of Physiology, University of Michigan Medical School, Ann Arbor, Mich. 48104 (U.S.A.)

(Accepted May 7th, 1969)

\section{INTRODUCTION}

In an extensive series of experiments summarized more than 40 years ago, $\mathrm{Cajal}^{1}$ described degenerative and other changes of pyramidal neurons of the cerebral cortex after severance of their axons. Many pyramidal neurons normally have collateral fibers and many of the fibers extend in recurrent, branching routes to higher cortical layers. Other collaterals have terminations upon nearby elements. The extent of collateral fields was increased if the deefferentation was done in immature brains of cats and dogs. Cajal ${ }^{1}$ reported no evidence that such collateral proliferation occurred in the mature or adult brain although he did not say specifically that mature animals were studied. It has been suggested ${ }^{4,8}$ that proliferation of axon collaterals is a possible explanation for developing supersensitivity in undercut or similarly traumatized cerebral cortex. The authors implied that collateral proliferation might promote an increasing amount of neuronal excitability by way of positive feedback circuitry.

This report, utilizing the Golgi impregnation method, is a quantitative evaluation of cortical pyramidal cell axon collaterals in 3 types of tissues, intact, undercut, and electrically stimulated undercut. Tentative conclusions were briefly mentioned in a symposium report ${ }^{5}$.

METHODS

Data are from 3 groups of adult cats (Table I). Three intact animals underwent no experimental procedures. Five cats with undercut or stimulated undercut cerebral cortices were prepared as previously described?. The 3 cats with undercut cerebral cortices were supersensitive at the time of being killed for histological study whereas the 2 that had received long-term electrical stimulation of the undercut tissue were not.

Our modifications of the Golgi-Cox method of impregnation were used. A complicating feature was that electrical studies had to be made on the widely exposed brain under oil for many hours in order to evaluate levels of supersensitivity. 
After much difficulty and experimentation over nearly 3 years, we found the following procedure to give the most satisfactory results in our adult cats.

At the conclusion of the acute experiments the chloralose anesthetized cats were given a lethal intravenous injection of sodium pentobarbital. The mineral oil was removed and the brain surface flushed off with room temperature saline. Intact animals were treated similarly except for the acute experiment. When the brain blanched, $4 \mathrm{~mm}$ sections were cut from marginal and suprasylvian gyri with a piece of sharp razor blade. Thickness of the sections was about $5 \mathrm{~mm}$. The pieces were removed quickly and individually placed in the fixing solution in $50 \mathrm{ml}$ dark bottles. The freshly made fixing solution was 40 parts double distilled water, 20 parts of $5 \%$ potassium dichromate, 16 parts of $5 \%$ potassium chromate, and 20 parts of $5 \%$ mercuric chloride. The dark bottles were placed in a light tight box and left undisturbed at room temperature for $40-80$ days.

Tissues were then washed in tap water, dehydrated through a series of graded alcohols, through ether-alcohol, and embedded in celloidin. Sections were cut at 100 to $125 \mu$ and placed in $70-80 \%$ ethyl alcohol. They were removed to a small dish of $5 \%$ ammonium hydroxide. As sections began to darken one was removed and checked for adequacy of staining under the microscope. Tissues, when ready, were removed to ether-alcohol $(50: 50)$ to dissolve the celloidin, placed on high optical quality slides, cleared in terpineol-xylene $(50: 50)$, and finally covered with Permount and high optical quality cover slips.

TABLE I

SAMPLING OF PYRAMIDAL NEURONS FROM THE MID-MARGINAL GYRUS IN THREE TYPES OF PREPARATIONS

\begin{tabular}{|c|c|c|c|c|c|c|c|c|c|}
\hline \multirow[t]{2}{*}{ Type } & \multirow[t]{2}{*}{$N$} & \multirow{2}{*}{$\begin{array}{l}\text { No. of } \\
\text { sections }\end{array}$} & \multirow{2}{*}{$\begin{array}{l}\text { Ave. No. cells } \\
\text { per section }\end{array}$} & \multicolumn{6}{|c|}{ Cell layer location } \\
\hline & & & & $I I$ & $I I I$ & $I V$ & $V$ & $V I$ & Total \\
\hline Intact & 3 & 25 & 4.0 & 81 & $y$ & 9 & 0 & 2 & 101 \\
\hline Undercut & 3 & 44 & 2.3 & 51 & 30 & 11 & 7 & 1 & 100 \\
\hline Stim Undercut & 2 & 28 & 3.6 & 65 & 15 & 12 & 2 & 6 & 100 \\
\hline
\end{tabular}

This procedure has produced excellent staining of cell bodies, dendrites, dendritic spines, and many axons in about $75 \%$ of the sections. There is an impression. that details of neuronal morphology are more adequately stained in the upper onehalf of the cortex in many of the sections. Some reflection of this may be seen in Table 1. The total sample of 301 cells was obtained from 97 tissue sections, from 8 cats, as described in Table I. Using a micrometer stage and 675 power magnification each section of tissue was systematically searched for pyramidal-type neurons that showed adequate staining and at least one well defined axon collateral. In order to ensure that corticifugal axons were selected it was necessary that they show a distinct 'downward course' distal to the first collateral. The occasionally encountered type P4 bifurcating intracortical neuron described by Sholl ${ }^{9}$ was not counted. The criteria

Brain Research, 16 (1969) 15-22 
were most difficult to follow in the study of neurons in undercut, unstimulated tissue and 44 sections were necessary to complete the sample in this group.

Four quantitative measures were made on each neuron selected, (1) axon length, (2) the average length of the two longest collaterals, (3) number of collaterals, and (4) the number of branches on all collaterals. Length measurements were made with an eyepiece calibrated scale and should be considered accurate to no more than $10 \mu$. Statistical $t$-tests ${ }^{2}$ were used in comparing differences in the 4 measures among the groups.

Likely synaptic points were noted if the postsynaptic structure could be identified.

Scale drawings and composite photomicrographs were made of selected representative pyramidal cells in each group.

RESULTS

The problem of the sampling of cells from Golgi stained material is recognized. Further, with the thickness of sections at 100 to $125 \mu$ which we found necessary in order to get good resolution of cellular elements, it is obvious that following many axons for any great distance would be unlikely. On the other hand, since the same procedure and criteria for selection were used on all tissues data would be comparable and justifiable comparisons could be made.

Table II contains the summary of all the data. Representative examples of the cells studied are shown in the drawings of Figs. 1-3. The composite photomicrographs are not shown because they are less illustrative than scale drawings.

Although there were apparent differences among the groups for lengths of axons and the average length of the 2 longest collaterals, only one difference was significant. Undercut tissue had neurons with significantly longer axons than did the intact group $(P<0.05,>0.02)$. It is known that Golgi studies on thicker sections of

\section{TABLE II}

SUMMARY OF DATA ON 4 QUANTITATIVE MEASUREMENTS

Lengths in microns. Means with standard errors are shown. NS, not significant. Probability values are shown in comparisons.

\begin{tabular}{|c|c|c|c|c|}
\hline & $\begin{array}{l}\text { Axon } \\
\text { length }\end{array}$ & $\begin{array}{l}\text { Ave. length } \\
2 \text { collaterals }\end{array}$ & $\begin{array}{l}\text { No. of } \\
\text { collaterals }\end{array}$ & $\begin{array}{l}\text { No. of } \\
\text { branches }\end{array}$ \\
\hline Intact (I) & $173 \pm 5.7$ & $80 \pm 4.3$ & $3.5 \pm 0.17$ & $4.2+1.03$ \\
\hline Undercut (UC) & $193 \pm 6.5$ & $90 \pm 6.0$ & $2.8 \pm 0.12$ & $3.0 \pm 0.26$ \\
\hline Stim Undercut (SUC) & $183 \pm 6.2$ & $85 \pm 4.3$ & $3.3 \pm 0.18$ & $3.5 \pm 0.28$ \\
\hline I vs. UC & $\begin{array}{l}<0.05 \\
>0.02\end{array}$ & NS & $<0.001$ & $<0.01$ \\
\hline I vs. SUC & NS & NS & $\gg 0.1$ & 0.1 \\
\hline UC vs. SUC & NS & NS & $\begin{array}{l}<0.05 \\
>0.02\end{array}$ & $>0.1$ \\
\hline
\end{tabular}




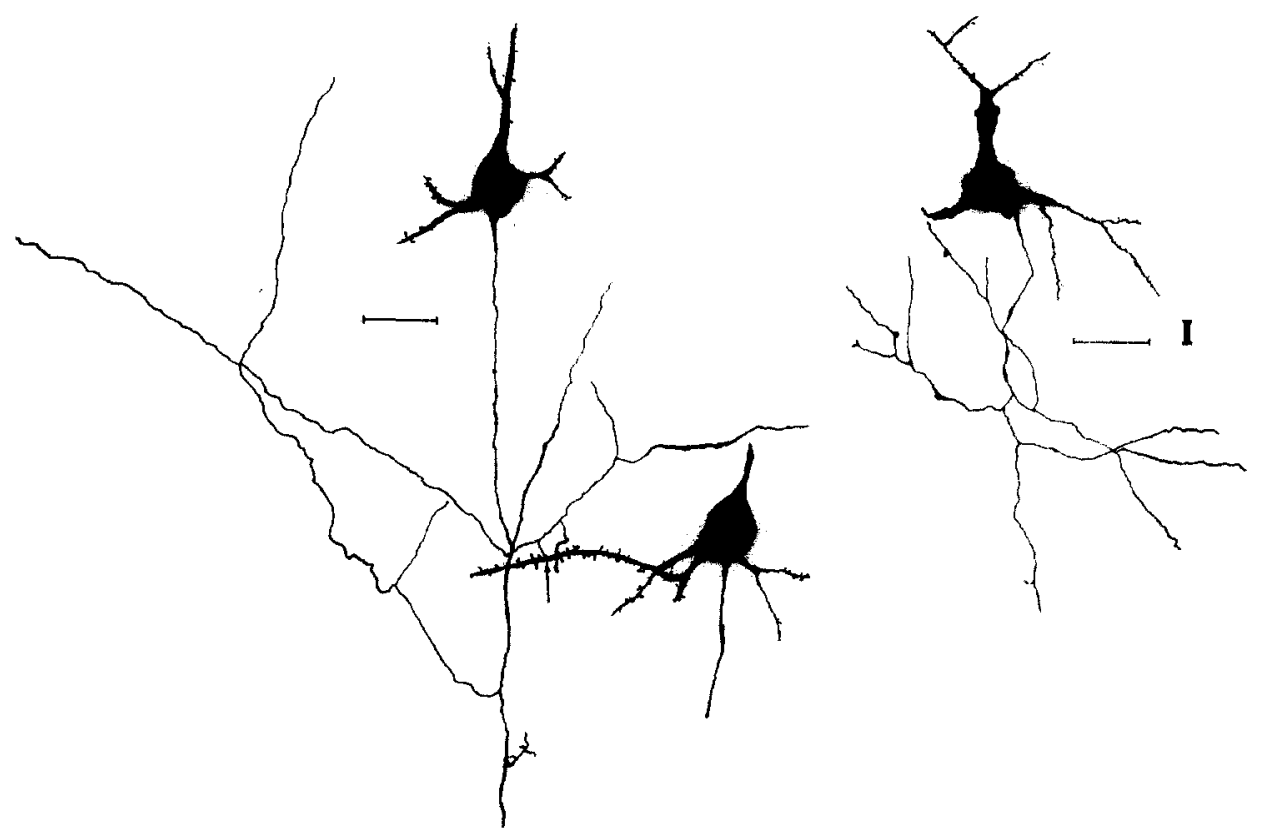

Fig. 1. Scale drawings of cortical cells from adult cats, intact marginal gyrus. Scales are $20 \mu$. Left (upper), layer II neuron. Cell has 5 collaterals and 4 branches. Right cell has 4 collaterals and 5 branches and is in layer IV. Small arrow points to fine terminal twig on basal dendrite.

cortical tissue from young animals show staining of lengthy axons and collaterals. In our adult tissues, as summarized in Table II, on the average only about onefourth of the total axonal length in the cortical gray, was stained. This fraction was greater for deeper lying cells and somewhat less for higher.

In spite of these limitations and the further, similar limitation that probably only a portion of the total number of axon collaterals and their branches were stained in some of the cells, Table II shows that significant differences were found. Pyramidal neurons in undercut tissue had fewer collaterals than did those in intact or those in stimulated undercut. Neurons in undercut tissue also had significantly fewer branches than did those in intact but were not different from stimulated undercut in this respect. Stimulated undercut was no different from intact in these two measures.

The scale drawings of 2 cells of each group shown in Figs. 1-3 are not obviously greatly different on first examination. Indeed, allowing for the fact that truly representative examples are difficult to select, studies of individual cells can yield only qualitative differences. But these substantiate the major findings. Fig. 2 shows one of the characteristic features of axons in undercut cerebral cortex, that of thickening or swelling, and beading of all or part of the axon and its components. These arrested degenerative changes were described and illustrated by Cajal ${ }^{1}$. Similar changes, though much less frequent, are seen in neurons of stimulated undercut tissue (Fig. 3).

As reported by others ${ }^{1,4}$ in cats and dogs under 30 days of age, some severed axons are transformed into arciform type axons with proliferation of collateral branches. No study of this type of cell could be made in the present work because they 


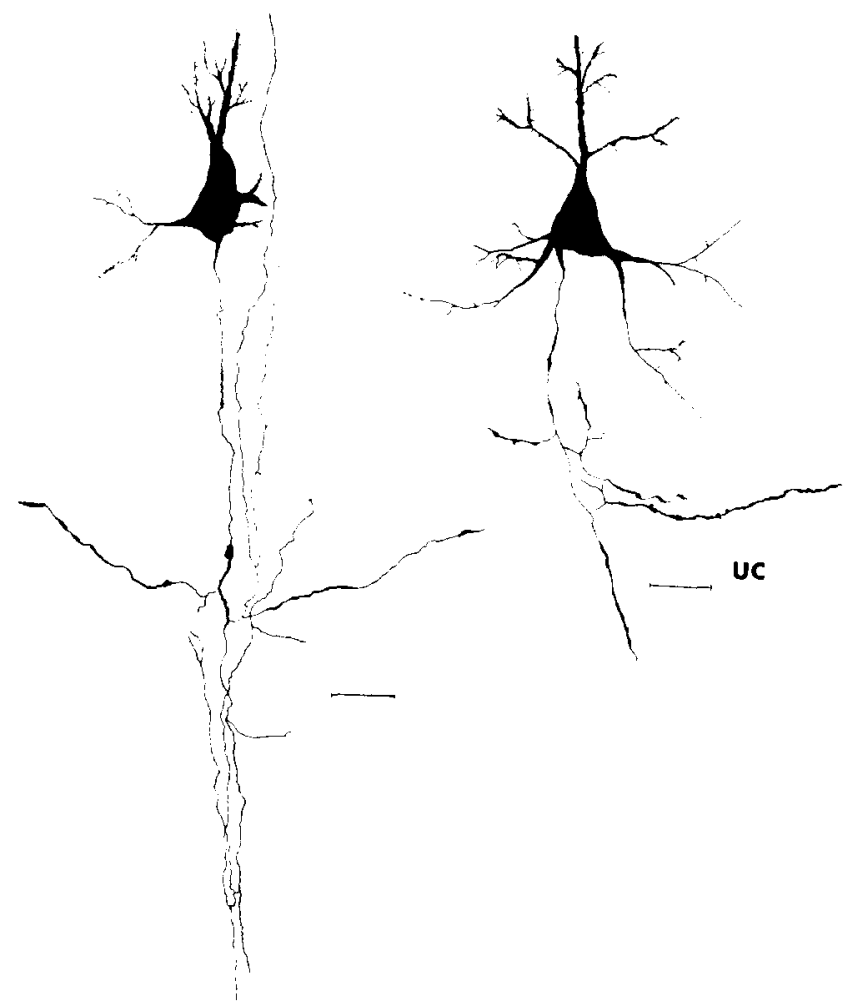

Fig. 2. Scale drawings of cortical cells from adult cats, undercut marginal gyrus. Scales are $20 \mu$. Left cell in layer III has 4 collaterals and 4 branches. Undercut operation 12 weeks prior to terminal experiment and histology. Right cell in layer II has 3 collaterals and 3 branches. Undercut 22 weeks.

were simply not seen in undercut preparations. Thus our results are based upon the readily identifiable axon with collaterals. Other work in progress on another type of preparation does suggest the presence of both hypertrophic bifurcating axons and axon collateral proliferation.

The other, largely qualitative difference is that small, terminal twigs of collateral branches are less frequently seen in undercut tissue. Terminals which appeared to end on dendritic spines and other structures were counted and Figs. 1 and 3 show examples of these likely synaptic loci. Fifty-one such terminations were seen in the 101 cells of the intact group. Of these 43 appeared to end on basal dendrites, 7 on apical dendrites and one on a soma. Twenty-five endings were found among the 100 cells of the undercut tissues, 13 were on basal dendrites, 11 on apical dendrites and one was axosomatic. In the sample of 100 cells in stimulated undercut tissue, 23 basal dendritic and 9 apical dendritic endings were found. Actual identification of any possible differences in synaptic morphology must await resolution with the electron microscope.

\section{DISCUSSION}

As mentioned before, axon collateral proliferation has been suggested as playing a major role in producing supersensitivity in deafferented and deefferented mature, 


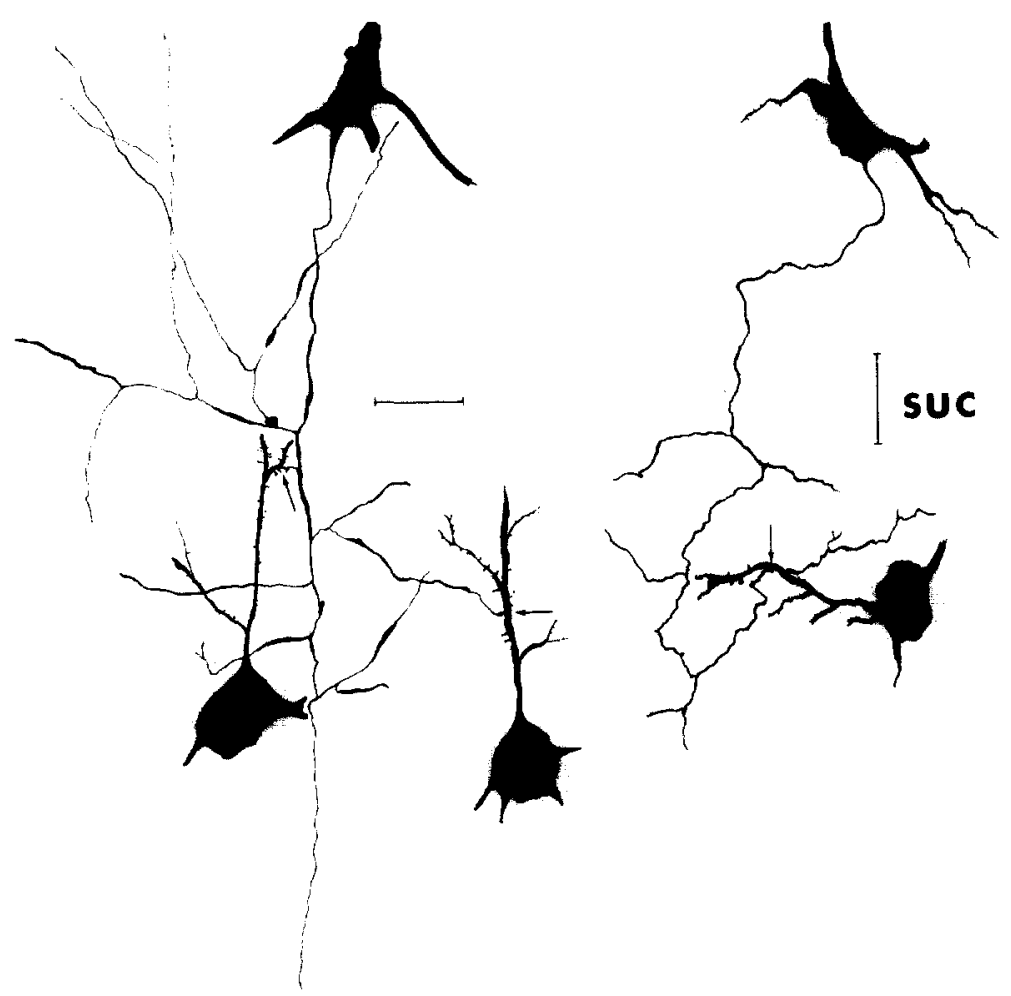

Fig. 3. Scale drawings of cortical cells from adult cats, stimulated undercut marginal gyrus. Scales are $20 \mu$. Left (upper) cell has 6 collaterals and 8 branches and is in layer II. Undercut 39 weeks, long-term stimulation first 9 weeks. Right (upper) cell in layer VI has 5 collaterals. Undercut 38 weeks, long-term stimulation 12 weeks during first 15 weeks. Arrows (left) point to fine terminal twigs, one on an apical dendritic shaft, one on an apical dendritic branch. Arrow on right points to partial entwining of a basal dendrite by an axonal branch.

cortical tissue. The present results are inconsistent with such an interpretation. Axon collaterals do not show any tendency to branch more in undercut tissue, and indeed, quite the contrary, branch significantly less than do collaterals of intact neurons. Similarly, significantly fewer collaterals are found in neurons of undercut tissue. The only support, and this not directly related to proliferation of collaterals, is the finding of longer axons in the undercut tissue, but for reasons stated above, axonal length is probably an unreliable and invalid measure.

These results, showing loss of collaterals and their branches in deafferented and deefferented pyramidal cells, suggest that in the mature mammalian cerebral cortex there is less 'growth potential' than there is in the immature brain. Deafferented cortex must contain pyramidal cells which have fewer action potentials and consequently metabolic activity of preserved cell bodies will be lower. It seems reasonable to conclude that new growth, or regrowth of axonal processes in deafferented and deefferented cortical pyramidal neurons probably does not normally occur in the mature adult brain.

The other major finding is related to the observation that stimulated undercut 
cortex does not develop supersensitivity ${ }^{7}$ and that such tissue contains pyramidal cells with significantly preserved apical dendritic spines ${ }^{5}$. Now it also appears that, not only are dendritic synaptic processes preserved, but on a statistical basis, axonal processes are preserved as well. The conclusion, that long-term electrical stimulation of deafferented and deefferented cerebral cortex tends to preserve both pyramidal cell dendritic synaptic loci and axonal processes, seems warranted. Since most synapses on cortical pyramidal cells are supposedly chemical in nature, they would be electrically inexcitable. It is suggested that the evidence from the present and from previous experiments showing preservation of pyramidal cell morphology in stimulated undercut cortex, points to postsynaptic excitation produced by presynaptic fiber activation.

Finally, it is suggested that the present observation of preservation of axon collaterals and branch points, may help to explain the conditioning experiments done previously ${ }^{6}$. In those studies cats were trained to give a forelimb flexion to conditional electrical stimulation of the cerebral cortex. After the cortex containing the electrodes had been undercut, conditioned responses were lost, but animals could be retrained over a long period of time. It seems reasonable to suppose that the efficacy of the additional training came about via activation of alternate collateral pathways involving successive neurons leading out of the undercut tissue.

SUMMARY

A quantitative study was made of pyramidal cell axon collaterals in Golgi impregnated adult cat cerebral cortex. Cellular samples were obtained from 3 groups, intact, undercut and long-term electrically stimulated undercut cortex.

Undercut tissue had cells with significantly fewer axon collaterals and fe:ver branches than did intact. Long-term electrically stimulated undercut tissue contained neurons which were not different from intact in these two measures. There was, therefore, a preservation of axonal morphology in stimulated undercut, adult cortex.

Results do not support a theory of axonal proliferation to explain supersensitivity in partially isolated mature cortex.

The preservation of axonal components and the preservation of dendritic spines, previously reported, indicates the prevention of some degenerative changes in certain cortical neurons brought about by long-term electrical stimulation.

\section{ACKNOWLEDGEMENTS}

This work was supported in part by U.S. Public Health Service Grant NB04119 .

The authors thank Miss Christine McBride for her careful histological work with the Golgi method.

\section{REFERENCES}

1 CAJAl, S. RAMón Y, Degeneration and Regeneration of the Nervous System, Vol. 2, R. M. May (Transl.), reprinted by Hafner, New York, 1959, 4th part, ch. II. 
2 McNemar, Q., Psychological Statistics, Wiley, New York, 1949, 388 pp.

3 Purpura, D. P., Factors in stability and seizure susceptibility of immature brain. In H. H. JASPER (Ed.), Basic Mechanisms of the Epilepsies, Little, Brown and Co., Boston. Mass., 1969, in press.

4 Purpura, D. P., And Housfrian, E. M., Morphological and physiological properties of chronically isolated immature neocortex, Exp. Neurol., 4 (1961) 377-401.

5 RuTLEDGE, L. T., Effects of stimulation on isolated cortex. In H. H. JAsPer (Ed.), Basic Mechanisms of the Epilepsies, Little, Brown, and Co., Boston, Mass., 1969, in press.

6 Rutledge, L. T., AND DOTY, R. W., Surgical interference with pathways mediating responses conditioned to cortical stimulation, Exp. Neurol., 6 (1962) 478-491.

7 Rutledge, L. T., Ranck, J. B., JR., And Duncan, J. A., Prevention of supersensitivity in partially isolated cerebral cortex, Electroenceph. clin. Neurophysiol., 23 (1967) 256-262.

8 Sharpless, S. K., Reorganization of function in the nervous system - use and disuse, Ann. Rev. Physiol., 26 (1964) 357-388.

9 Sholl, D. A., The Organization of the Cerebral Cortex, Wiley, New York, 1956, 125 pp. 